\title{
第50回（2014 年度）城戸奨励賞 選考経過および講評
}

\section{I ．選考経過}

\section{1．選考対象となる論文}

選考委員長 本郷一夫

対象は, 2014 年度の『教育心理学研究』(第 62 巻) に発表された論文のうち，著者（共著者を含む）が公刊 時に 35 歳未満である論文である。また原則として, 同一執筆者に対し重ねて授与することはしない。今年 度は， 3 論文が選考の対象となった。

\section{2. 選考委員(敬称略)}

本郷一夫 (委員長), 井上俊哉, 氏家達夫，惠羅修吉， 及川 恵, 小泉令三, 坂上裕子, 中條和光, 外山美樹, 豊田弘司，西山久子，林 創，森永康子，安永 悟，山 本博樹

\section{3. 選考方法}

選考は「城戸奨励賞基金に関する内規」および「城 戸奨励賞論文選考細則」(いずれも学会ホームページに掲 載) に基づいて行われた。

\section{4. 選考結果}

第 1 次選考において， 7 委員より推薦が 1 論文， 5 委員より推薦が 1 論文, 4 委員より推薦が 1 論文あっ た。

細則により，2 名以上から推薦のあった 3 論文を第 2 次選考の対象とした。

第 2 次選考において, 各委員が上記 3 論文の評定を 行い，その結果の一覧表をもとに最終選考を行った。 その結果, 以下の 1 論文を受賞論文として最終的に決 定した。

・後藤由佳論文 (英語語彙の意味範囲に関する不十分な理 解とその修正, 第 62 巻第 1 号, pp. 1-12)

\section{II . 講 評}

\section{後藤由佳論文「英語語彙の意味範囲に関する不十分 な理解と谷修正」}

講評者 豊田弘司

英単語をどのような文脈（状況）で使用するかを理 解することは, 英語学習の 1 つの課題である。本論文 は，この課題に実践指導的な視点から取り組んだもの である。大学生を対象として, 実験 I では意味範囲の 理解は十分とはいえない結果を示した。そして，その 改善のために，実験IIでは，英文適用の誤文を提示し， その使用が正しいかどうかの判断を求めた後, この使 用が正しくないことを指摘し, 異なる英単語を使用し なくてはならない理由を示した (練習群)。また，間違 えて使用した場合に，現実ではありえないような意味 になるというエピソードを提示した (エピソード群)。 その結果, 練習やエピソードを追加することの効果が 認められている。練習群及びエピソード群ともに, 誤 文を提示しているので，誤文を提示することの有用性 が示され，さらに，エピソード群は動機づけを高める という結果も見いだされており，興味深い。

本論文で検討された英単語の数は限定されているが, 英語の意味範囲が日本語のそれとは異なることを理解 した英語学習の重要性を指摘した点は, 教育的意義が ある。ただし, 著者も言及しているように, 学習者の 英語力の水準による効果の違いも今後の検討課題であ るし，実験 I とIIをあわせた研究計画もありえる。し かし, 英単語の使用範囲を理解させるという教育実践 への 1 つの視点と, 具体的な実践を意識させる教材提 供のアイデアは, 評価できる。また, 論文全体の論旨 の明快さ, 読みやすさは高く評価できる。さらに, 教 育実践現場での実用可能性及び今後の新たなアイデア の提供の可能性も加味して, 城戸賞の基準に到達した 論文として評価した。著者の今後の新たな実践的研究 の発展を期待したい。 


\section{城戸奨励賞を受賞して}

\section{英語語彙の意味範囲に関する不十分な理解とその修正}

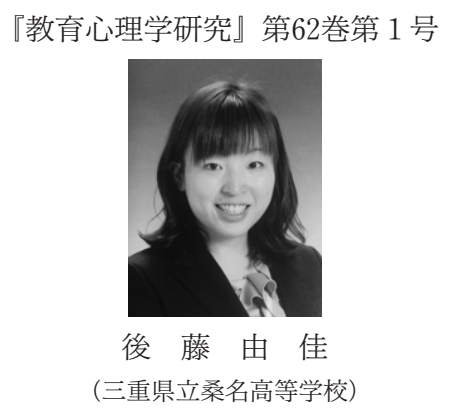

この度は，城戸奨励賞という名誉ある賞をいただき 大変光栄に存じております。

\section{本研究の背景}

英語の語彙を学習する際に，日本語と英語を対にし て訳語を暗記するだけの学習方法をとる場合がありま す。例えば受験などで，大量の単語を短時間で覚えよ うとすると，1語にかける時間を最小限に抑えたいと 考え，訳語を覚える以上の学習をしにくくなります。 しかし，英単語の訳語を暗記するだけでは，どのよう な文脈でその単語を使用できるのかを理解することは できません。特に使用される頻度の高い動詞（句）に ついては，英語と日本語の意味範囲が大きくずれる場 合が多く, 暗記した訳語の使用方法に引つ張られて不 適切な使用をしてしまうことが予測されます。

このような問題意識から，英語の語彙の意味範囲が どの程度理解されているのかを調べ, 理解が不十分で あればどのような教授方法が有効かを検証したいと考 えました。さらに, 学習者の英単語学習に対する学習 方略によって, 意味範囲の理解の程度や教授方法の効 果の程度に関連があるかどうかを調べたいと考えまし た。

\section{本研究の概要}

5 つの動詞（句), climb, memorize, borrow, teach, put on は, 使用頻度の比較的高い基本的な動詞（句） ですが，それぞれ日本語の「登る」「覚える」「借り る」「教える」「着る」とは使用できる意味の範囲が異 なっているため, 日本語に引つ張られて間違った使用 をしやすい語彙であることが推察されます。例えば climb は「手足など自分の身体の力を使って登る」場
合に使用するのですが，日本語の登るにはそのような 限定はありません。よって climbの意味範囲を知ら ないと, I climbed a mountain by cable car.などの誤 文を作ってしまう可能性が高いと考えられます。実際 に本研究では先に挙げた動詞（句）についてこのよう な誤文を提示して間違っていることを指摘できる正答 率は $60 \%$ にとどまり, 理解が不十分であることが示 されました。

そこでこれらの動詞 (句) の意味範囲の教授法とし て 3 つの群を設定しました。辞書群, 練習群, エピ ソード群です。辞書群では辞書に準じる形で語法の提 示をし, 練習群では誤文指摘する練習をさせ，エピ ソード群では間違えた文脈でその動詞（句）を使用し た場合に予想外の意味が生じてしまうエピソードを提 示しました。

それぞれの教材を提示した後に, 事後テストと事後 アンケートを実施し，3つの観点から結果をみました。 (1)事後テストの点数, (2)学習方法の理解 (有効性認知, 学習方略の見直しなどの事後アンケート項目), (3)動機づけ

(興味, 意欲などの事後アンケート項目) です。まず， (1)事 後テストの点数については, 練習群とエピソード群で 高く, 正答率は 90\%でした。次に(2)学習方法の理解 に関しては全ての群で高くなりました。最後に(3)動機 づけという観点では, エピソード群のみで高く, 辞書 群と練習群では低くなりました。辞書群では語法に着 目する学習方法への理解は得られるものの, 正答率は 不十分で, 動機づけは高めることができませんでした。 練習群は正答率が高く, 学習方法の理解も得られるも のの, 動機づけを高めることができませんでした。エ ピソード群は正答率, 学習方法の理解, 動機づけのす べての項目で高い值を得ることができました。 
さらに事前アンケートで英単語の学習方略について の調査を行いました。英単語を学習するときに日本語 の訳語と対応させて終わるのではなく, その単語が使 用される文脈や状況を考慮する「文脈利用方略」の 1 項目が因子分析で取り出されました。そして文脈利用 方略の高低と教授方法の組み合わせによって，学習方 法の理解や動機づけに交互作用 (ATI) が生じること が示唆されました。具体的には辞書群は, (2)学習方法 の理解，(3)動機づけが高くなりました。練習群は文脈 利用方略が低い人の方が(2)学習方法の理解, (3)動機づ けが高くなりました。エピソード群は文脈利用方略に よる有意な差はなく, 文脈利用方略の高低にかかわら ず教材の内容がよく理解され，(2)学習方法の理解，(3) 動機づけがともに高くなりました。

以上を踏まえて, 教育実践にどのように活かすこと ができるかを考えてみたいと思います。事後テストの 正答率が高かったのは練習群とエピソード群でした。 練習群は具体的な誤文に即して練習したことで誤りや すい用例に注意が向き，意味範囲に対する知識が強固 なものになったと推察でき, エピソード群は日常生活 ではありえないような予想外の意味になってしまう工 ピソードを知ったことで誤った語法が印象深く頭に残 り，意味範囲に対する知識が強固なものになったと考 えられます。辞書の語法を読むだけでは単語の意味範 囲を習得することは難しいので，授業の中で面白い誤 文を提示して解説することや，誤文を見分ける練習な どを取り入れることが意味範囲の理解の促進につなが ると考えられます。ただし, 英語の授業において全て の単語の意味範囲を取り上げることは不可能です。し たがって, 学習者自身がその後の学習で単語の意味範 囲に意識を向けていけるように，授業の中で意味範囲 の違いを印象深く受け止め, 動機づけを高める仕掛け
をすることが重要です。その際にエピソード群のよう に意外な意味が生じてしまう誤文を提示することが効 果的であると考えます。また, 実際の授業では, 複数 の教授方法を組み合わせて使用することができます。 エピソード群や練習群のような教授方法とともに, 辞 書の語法を読むことも授業で取り上げることで，今後 の自学自習の支援につながると考えます。例えば climbの語法で「手足など自分の身体の力を使って登 る」という記述を見て，「山登りには使えるけれど， ケーブルカーで山を登る場合には使えない」など具体 的な場面を想定して意味範囲を理解することができる ようになれば, 誰かに解説してもらわなくても自学自 習で意味範囲を習得していくことができるようになり ます。

最後に今後の展開として, (1)英語の学力が異なる層 に対しても有効であるか，(2)英語の授業として語彙の 意味範囲を扱う場合にはどのように授業を構成できる か, (3)意味範囲学習後に学習方略の変化が起こるか否 か, (4)いくつかの意味範囲を取り上げて学習すること で，他の単語学習にも転移して意味範囲を自習するよ うになるかについて検証してみたいと考えています。

\section{謝辞}

本論文の作成にあたり, 前早稲田大学教育学研究科 教授・麻柄啓一先生には丁寧なご指導をいただきまし た。その過程で, 研究の楽しさや, アイデアを形にし ていくことの喜びを学びました。また丁寧かつ的確な ご指摘をくださいました查読者の先生方, 実験に協力 していただいた大学生の皆様, 研究計画や実験教材の 作成にお力添えいただいた早稲田大学教育学研究科の 皆様に厚く御礼申し上げます。 